\title{
Using Technology Acceptance Model 3 (TAM 3) at Selected Private Technical High School: Google Drive Storage in E-Learning
}

\author{
Lila Setiyani, Femmy Effendy \& Annisa Anggraini Slamet \\ STMIK Rosma, Karawang, Indonesia \\ lila@ rosma.ac.id
}

\begin{abstract}
ARTICLE HISTORY
Received : 2021-05-10

Revised : 2021-07-02

Accepted : 2021-07-10
\end{abstract}

\section{KEYWORDS}

Analysis

E-Learning

Google Drive

TAM 3

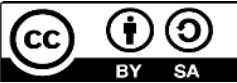

\begin{abstract}
During the Covid-19 pandemic, almost all schools around the world conduct the learning process by E-Learning courses. This brings consequences for various learning materials to be uploaded and stored in Google Drive. The purpose of this quantitative study was to determine the acceptance of Google Drive in ELearning using the Technology Acceptance Model 3 (TAM 3) method at selected private vocational-technical high schools in Indonesia, i.e., STMIK Rosma. Sampling was conducted on 40 information system students at STMIK Rosma out of 83 student population using a proportionate stratified random sampling technique. Based on the results, students accepted Google Drive services in STMIK Rosma E-Learning with the following details, Subjective Norms (NS) had a significant influence on Image (CT) and Perceived Usefulness (KG), Image (CT) had a significant influence on Perceived Usefulness (KG), Perceived Enjoyment (KS) had a significant influence on Perceived Ease of Use (KP), and Perceived Ease of Use (KP) had a significant influence on Perceived Usefulness (KG). Thus, Google Drive is useful and needed in e-learning during the COVID19 pandemic.
\end{abstract}

\section{Introduction}

With the rapid development of information technology, exchanging information is easier without having to worry about place, distance, and time limitations. Information technology cannot be separated from the development of computer technology. Therefore, education is also required to utilize and adapt existing information technology to improve the quality of education. Information technology makes it easier for universities to carry out the teaching process without face-to-face meetings but through E-Learning. Thus, the E-Learning system is very influential in the education field, where elementary schools to tertiary institutions carry out the learning process through it.

During the Covid-19 pandemic, STMIK Rosma conducted an online learning process through ELearning. Students can study from home without attending the class and meeting face to face with the lecturers. The lecturers upload various learning materials for their students in the form of word files, PowerPoint presentations, photos, and videos. Various materials are uploaded and stored on Google Drive. Therefore students can read or watch material from the lecturers.

Google Drive is a storage service media owned by Google, Inc. Google Drive was founded in April 2012 and originated from Google Docs, and the Google Drive application provides a free storage capacity of 15 GigaBytes (GB) for its users (Trilaksono, 2020). Currently, Google Drive is a storage medium used by students to upload assignments given by lecturers and used by lecturers to upload learning materials. (Ariessanti et al., 2012).

The researchers were interested in conducting an analysis to determine the acceptance of Google Drive in E-Learning STMIK Rosma. The purpose of this study was to find out how STMIK Rosma students use Google Drive in the learning process. This study used the TAM (Technology Acceptance Model) 3 model and collected the data by distributing questionnaires.

TAM (Technology Acceptance Model) is a method used to measure the acceptance of technology. TAM offers a theory as a basis for studying and understanding user behavior in using and receiving an information system (Wida et al., 2016). Venkatesh \& Davis (2000) developed the TAM 2 theory to further explain the construct of perceived usefulness. Then, Venkatesh \& Bala (2008) combined TAM 2 with perceived ease of use developed by Venkatesh (2000) to become TAM 3 (Ladepi, 2018). Therefore, researchers used the TAM 3 method to determine the acceptance of Google Drive in E-Learning at STMIK Rosma. 
Mainly, TAM was used by companies. However, this study used TAM in the education field. Companies usually use Google Drive, but in this study, Google Drive is used for e-learning at STMIK Rosma. Thus, this is a novelty because no one has disczussed it. Some previous researchers (Warsito \& Yuliandini, 2017; Pudjastawa \& Cantika, 2020; Saktiono, 2019; Rumini, 2019) discussed google drive in an institution or company and not in the education field. This study will have implications for the usefulness of Google Drive in e-learning. If the acceptance is good, it will have implications on the level of investment from the university. This study will automatically have an impact on the university to be consistently using Google Drive. Based on this description, researchers had the interest to analyze the acceptance level of Google Drive in e-learning at STMIK Rosma.

\section{Literature Review}

\subsection{Analysis}

According to (Setiawan, 2020), analysis is an investigation of an event (essay, deed, etc.) to find out the real situation (causes, issues, and so on).

An analysis is an activity consisting of activities such as distinguishing, describing, sorting to be classified and regrouped according to certain criteria, then finding the relationship and interpreting the meaning (Airifin, 2009). Meanwhile, according to Sugiyono in Fitriani (2020) analysis is an activity to look for a pattern, besides as a way of thinking related to systematic testing to determine parts, relationships between parts, and their relationship with the whole.

\subsection{Technology Acceptance Model (TAM)}

There are several measurement methods on the acceptance level of an information system, namely Theory of Planned Behaviour (TBP) (Sakdiyah et al., 2019; Ananto Setiawan et al., 2020; Widyastuti et al.,
2020), Technology Acceptance Model (TAM) (Putra et al., 2018; Librado, 2017; Roziqin et al., 2021) and Unified Theory of Acceptance and Use of Technology (UTAUT) (Chandra \& Novita, 2020; Nadiyah Hidayati, 2020). Of these several acceptance methods, TAM is the most widely used today. Therefore, this study used the TAM method. According to Surendran (2012), TAM has been widely used in various studies and verified by several different situations, conditions and objects to examine the behavior of individual technology acceptance in various information system constructions.

Technology Acceptance Model (TAM) is a theory to explain the individual acceptance of information technology (Palapa \& Saifudin, 2021). TAM is an information technology system acceptance model adopted from the Theory of Reasoned Action (TRA) model. Davis first introduced TAM in 1989 (Sefrika, 2018). According to Fatmawati (2015), before TAM, there was the Theory of Reasoned Action (TRA) developed by Ajzen \& Fishbein (1975). Based on previous studies on attitude and behaviour theory, TRA emphasized attitudes viewed from a psychological point of view (Endang Fatmawati, 2015).

In a recent development, TAM 3 has a new dimension to PEOU. The TAM development aims to form predictable and explainable basic assumptions driving the use of evolving technology (Adi Setiawan \& Sulistiowati, 2018). TAM 3 has 17 additional variables such as anchor factors (Computer selfefficacy, Perception of efficacy, Computer anxiety, and Computer playfulness), adjustment factors (Perceived enjoyment, Objective usefulness), Image, Job relevance, Output quality, Result demonstrability, Subjective norm, Experience, and Voluntariness affecting Perceived usefulness and Perceived ease of use to then affecting Behavioral intention and Use Behavior (UB) (Adetimirin, 2015). 


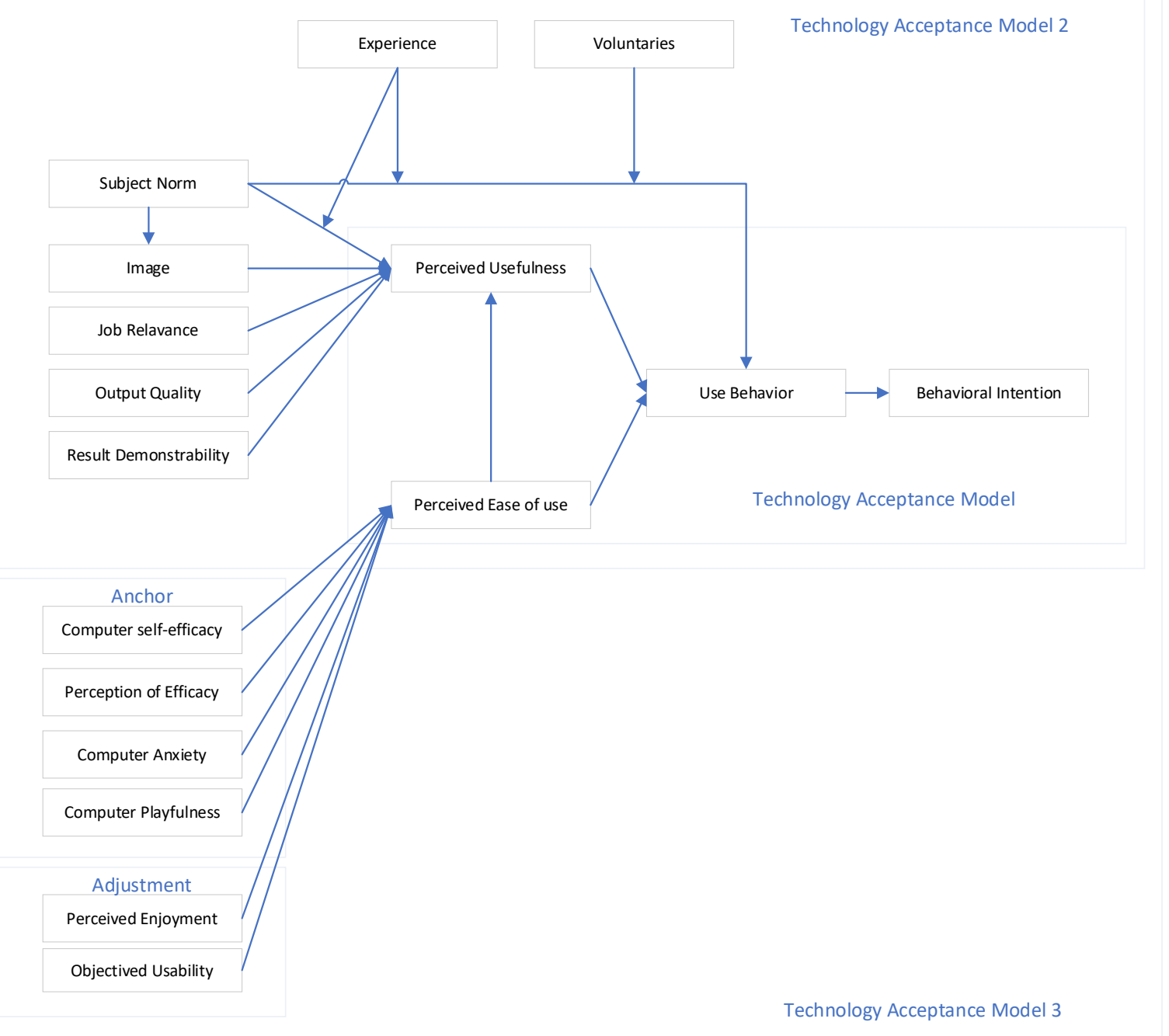

Figure 1. TAM 3: Model Source: (Adetimirin, 2015)

17 TAM 3 variables are explained as follows (Prasetyo, 2016):

a. Subjective norm is a human thought to do something or not at all

b. Experience is a benchmark variable for determining subjective norms to determine the perceived usefulness to directly determine behavioural intention.

c. The voluntary level also affects subjective norms in determining behavioural intention.

d. Image can directly influence the perceived usefulness and can be influenced by subjective norms.

e. Job Relevance shows the perception of information or technology's importance in helping or influencing the work. f. Output Quality shows individual belief in an information system or technology used to provide good results for the work.

g. Result Demonstrability shows the measurable results of information technology.

h. Computer Self-Efficacy shows the belief to perform certain tassks using computers.

i. Perception of External Control describes the perception of infrastructure or other things supporting the information system.

j. Computer Anxiety is related to reluctance in using a computer.

k. Computer Playfulness is related to human spontaneity to interact with computers.

1. Perceived Enjoyment shows the fun perceived regardless of the results of information systems.

m. Objective Usefulness shows the efforts required to complete a particular task. This component is not a 
human perception because it can be scientifically measured.

n. Perceived Ease of Use defines the human perception to use the information system easily.

o. Behavioral Intention relates to the formulated plan to do or not do particular behaviour in the future.

p. Perceived Usefulness shows the belief in using information systems to improve work performance.

q. Use behaviors show individual behavior in using an information system.

\subsection{E-Learning}

Electronic Learning or commonly referred to as ELearning is a new way of teaching and learning using electronic media, especially the internet as a learning system (Sakdiyah et al., 2019).

E-Learning is a learning method using electronic media or certain devices to deliver learning materials (Riski Nurida Rahmawati \& I Made Narsa, 2019).

Developing e-learning aims to support the teaching and learning process and to improve the quality of services to students (Shandyastini \& Novianti, 2016). According to Novak in (Balaji et al., 2016), e-learning can increase interactivity and learning efficiency by giving students a higher potential to communicate

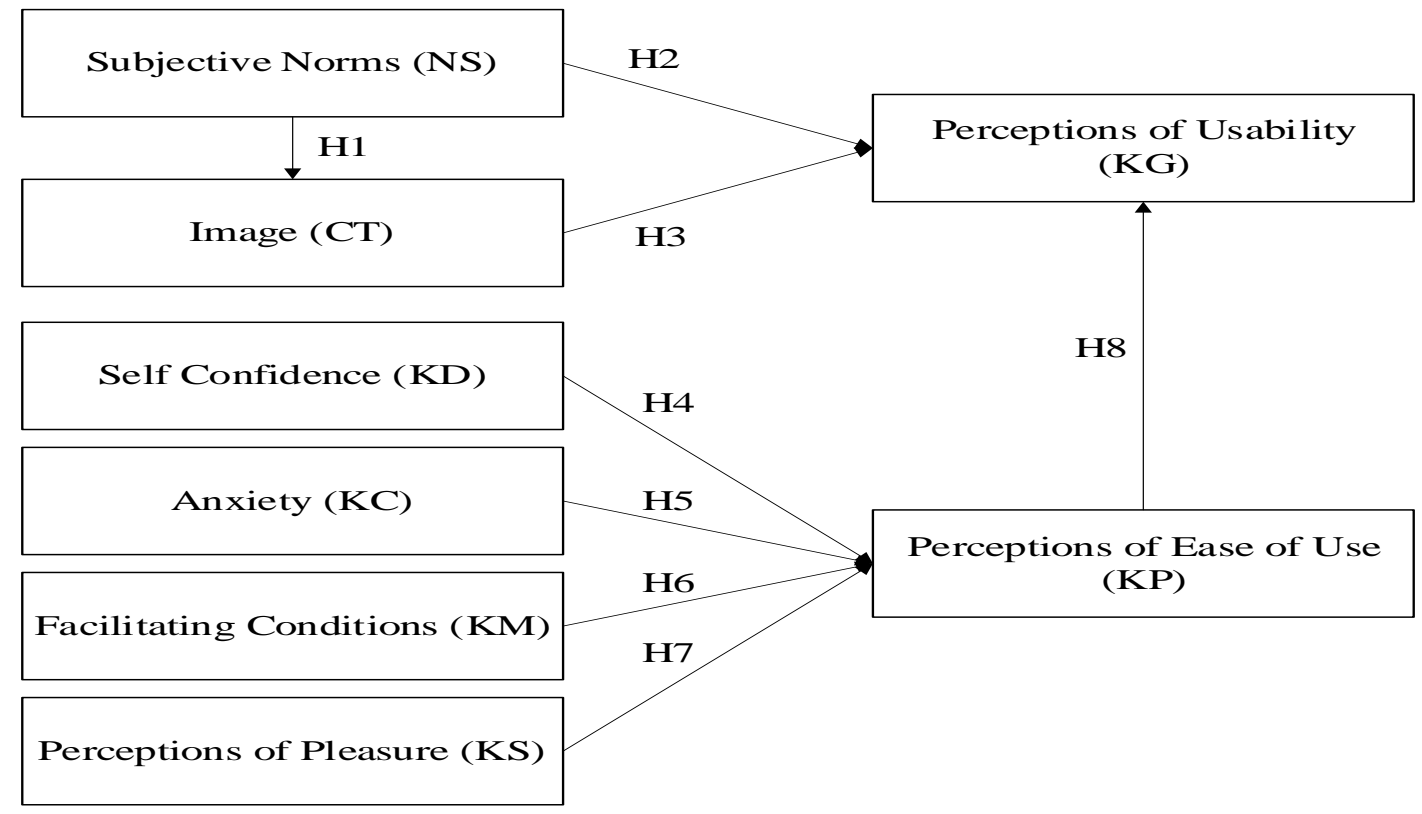

Figure 2. Model

Based on the model above, the hypotheses are as follows:

H1: Subjective Norms (NS) has a significant influence on Image (CT).

H2: Subjective Norms (NS) has a significant influence on Perceived Usefulness (KG). more with lecturers, colleagues and access more learning materials.

\subsection{Google Drive}

Google Drive is one of the services offered by Google to store documents or files for free or for a fee, depending on the storage memory capacity (Sijabat et al., 2020).

Google Drive is an internet medium to convey messages or information to support the E-Learning learning process (Ariessanti et al., 2012).

\section{Method}

This study used TAM 3 model to determine the acceptance of Google Drive in E-Learning at STMIK Rosma. Of the 17 constructs in TAM 3, this study uses eight constructs, namely Subjective Norms (NS), Image (CT), Self-Confidence (KD), Anxiety (KC), Facilitating Conditions (KM), Perceived Enjoyment (KS), Perceived Ease of Use (KP) and Perceived Usefulness $(\mathrm{KG})$. The population of this study were 83 students of STMIK Rosma Information System in the class of 2017 - 2020. This study used Proportionate Stratified Random Sampling on 40 samples. Data were collected by distributing a google form questionnaire Data processing was carried out using Smart PLS (Partial Least Square) to predict the relationship between constructs and obtain latent variable values as linear aggregates. 
H6: Facilitating Conditions (KM) has a significant influence on Perceived Ease of Use.

H7: Perceived Enjoyment (KS) has a significant influence on Perceived Ease of Use.

H8: Perceived Ease of Use (KP) has a significant influence on Perceived Usefulness.

\section{Results}

\subsection{Respondents}

In this study, respondents were grouped based on gender, age, and study program, which can be seen in the following table:

Table 1. Characteristics of Respondents by Gender

\begin{tabular}{|c|c|c|}
\hline Gender & Total & Percentage \\
\hline Men & 19 & $47.5 \%$ \\
\hline Woman & 21 & $52.5 \%$ \\
\hline Total & 40 & $100 \%$ \\
\hline $\begin{array}{l}\text { Based on } \mathrm{T} \\
\text { spondents }(21\end{array}$ & $\begin{array}{l}\text { there } \\
\text { ts or } 52\end{array}$ & more female \\
\hline \multicolumn{3}{|c|}{ Table 2. Characteristics of Respondents by Age } \\
\hline Age & Total & Percentage \\
\hline$<20$ Years & 7 & $17.5 \%$ \\
\hline 20-30 Years & 33 & $82.5 \%$ \\
\hline Total & 40 & $100 \%$ \\
\hline
\end{tabular}

Based on Table 2, there were 7 respondents $(17.5 \%)$ aged $<20$ years and 33 respondents $(82.5 \%)$ aged 20-30 years.

Table 3. Characteristics of Respondents by Year of Study Program

\begin{tabular}{lcc}
\hline Study Program & Total & Percentage \\
\hline $\begin{array}{l}\text { Information } \\
\text { System 2017 }\end{array}$ & 10 & $25 \%$ \\
\hline $\begin{array}{l}\text { Information } \\
\text { System 2018 }\end{array}$ & 10 & $25 \%$ \\
\hline $\begin{array}{l}\text { Information } \\
\text { System 2019 }\end{array}$ & 11 & $27.5 \%$ \\
\hline $\begin{array}{l}\text { Information } \\
\text { System 2020 }\end{array}$ & 9 & $22.5 \%$ \\
\hline Total & $\mathbf{4 0}$ & $\mathbf{1 0 0 \%}$
\end{tabular}

Based on table 3, there were 10 respondents from Information System 2017, 10 respondents from Information System 2018, 11 respondents from Information System 2019, and 9 respondents from Information System 2020.

\subsection{Validity Test}

Instrument items are declared valid if there is a similarity between the collected data and the actual data on the object under study (Trihandayani \& Abdillah, 2019).

The indicator is considered valid if it has an AVE value above 0.5 or all extreme loading values of $>0.7$. It can be concluded that the measurement meets the convergent validity criteria.

Table 4. Validity Test Results

\begin{tabular}{|c|c|c|c|c|}
\hline Variable & Statement & Code & Loading & AVE \\
\hline Subjective Norms (NS) & $\begin{array}{l}\text { My lecturer encourages me to use Google Drive in } \\
\text { E-Learning as a storage medium. }\end{array}$ & NS 2 & 1.000 & 1.000 \\
\hline Image $(\mathbf{C T})$ & $\begin{array}{l}\text { Using Google Drive in E-Learning as a storage } \\
\text { medium makes me appear skilful in utilizing } \\
\text { technology. }\end{array}$ & CT 2 & 1.000 & 1.000 \\
\hline Self Confidence (KD) & $\begin{array}{l}\text { I have complete confidence in operating Google } \\
\text { Drive. }\end{array}$ & KD 1 & 1.000 & 1.000 \\
\hline \multirow{2}{*}{ Anxiety (KC) } & $\begin{array}{l}\text { I feel worried if I press the wrong button while } \\
\text { using Google Drive. }\end{array}$ & $\mathrm{KC} 1$ & 0.782 & \multirow{2}{*}{0.767} \\
\hline & $\begin{array}{l}\text { I feel worried when using Google Drive because I } \\
\text { don't have a good ability to use it. }\end{array}$ & KC 3 & 0.960 & \\
\hline \multirow{2}{*}{$\begin{array}{l}\text { Facilitating Conditions } \\
\text { (KM) }\end{array}$} & $\begin{array}{l}\text { Availability of facilities needed to use Google } \\
\text { Drive (for example, laptop/computer, cellphone, } \\
\text { internet network). }\end{array}$ & KM 1 & 0.850 & \multirow[t]{2}{*}{0.788} \\
\hline & $\begin{array}{l}\text { I have the required knowledge to use Google Drive } \\
\text { (for example, knowledge to use a computer). }\end{array}$ & KM 3 & 0.924 & \\
\hline
\end{tabular}




\begin{tabular}{|c|c|c|c|c|}
\hline Variable & Statement & Code & Loading & AVE \\
\hline $\begin{array}{l}\text { Perception of } \\
\text { Enjoyment }(\mathrm{KS})\end{array}$ & $\begin{array}{l}\text { I like using Google Drive because it is easier as a } \\
\text { storage medium. }\end{array}$ & KS 1 & 1.000 & 1.000 \\
\hline \multirow{3}{*}{$\begin{array}{l}\text { Perceived Ease of Use } \\
\text { (KP) }\end{array}$} & I find Google Drive very flexible to use. & KP 1 & 0.897 & \multirow{3}{*}{0.824} \\
\hline & $\begin{array}{l}\text { Google Drive features are very clear and easy to } \\
\text { understand. }\end{array}$ & KP 2 & 0.907 & \\
\hline & I find the Google Drive system easy to operate. & KP 3 & 0.919 & \\
\hline \multirow{3}{*}{$\begin{array}{l}\text { Perceived usefulness } \\
\text { (KG) }\end{array}$} & $\begin{array}{l}\text { By using Google Drive, there is no need for } \\
\text { memory cards as storage media. }\end{array}$ & KG 1 & 0.800 & \multirow{3}{*}{0.697} \\
\hline & $\begin{array}{l}\text { The use of Google Drive can reduce the possibility } \\
\text { of losing files stored on Google Drive. }\end{array}$ & KG 2 & 0.858 & \\
\hline & $\begin{array}{l}\text { Google Drive is very useful for me as a storage } \\
\text { medium. }\end{array}$ & KG 3 & 0.846 & \\
\hline
\end{tabular}

In Table 4, all statement items for each variable met the requirements of the convergent validity test by having a loading value of $\geq 0.7$ and also, the AVE value for each variable had a value of more than 0.5. Thus, all indicators in the variables in this study were valid.

Table 5. Correlation Value Between Variables

\begin{tabular}{|c|c|c|c|c|c|c|c|c|c|}
\hline & AVE & CT & KC & KD & KG & KM & KP & KS & NS \\
\hline CT & $\mathbf{1 . 0 0 0}$ & $\mathbf{1 . 0 0 0}$ & & & & & & & \\
\hline KC & $\mathbf{0 . 7 6 7}$ & 0.027 & $\mathbf{0 . 8 7 6}$ & & & & & & \\
\hline KD & $\mathbf{1 . 0 0 0}$ & 0.384 & -0.326 & $\mathbf{1 . 0 0 0}$ & & & & & \\
\hline KG & $\mathbf{0 . 6 9 7}$ & 0.609 & -0.004 & 0.566 & $\mathbf{0 . 8 3 5}$ & & & & \\
\hline KM & $\mathbf{0 . 7 8 8}$ & 0.443 & -0.166 & 0.564 & 0.673 & $\mathbf{0 . 8 8 8}$ & & & \\
\hline KP & $\mathbf{0 . 8 2 4}$ & 0.532 & -0.192 & 0.622 & 0.733 & 0.639 & $\mathbf{0 . 9 0 8}$ & & \\
\hline KS & $\mathbf{1 . 0 0 0}$ & 0.578 & -0.105 & 0.530 & 0.746 & 0.606 & 0.792 & $\mathbf{1 . 0 0 0}$ & \\
\hline NS & $\mathbf{1 . 0 0 0}$ & 0.291 & -0.291 & 0.036 & 0.177 & 0.126 & 0.289 & 0.401 & $\mathbf{1 . 0 0 0}$ \\
\hline
\end{tabular}

After testing the validity using loading and AVE values, the discriminant validity test was carried out to compare the cross-loading value of the construct and the correlation between constructs (Sirait, 2021).

Based on the table above, the correlation value for each variable with the variable itself had a more excellent value than with other variables. Thus, all variables in this study were declared valid and had met the discriminant validity test.

\subsection{Reliability Test}

After testing the validity, the reliability test was carried out by just one measurement. The results are compared with other questions to measure the correlation between the answers to the questions (Karim et al., 2020).

If the correlation is 0.7 , the item is reliable, and on the contrary, if the correlation value is below 0.7 , the thing is not reliable.
Table 6. Reliability Test Results

\begin{tabular}{lc}
\hline \multicolumn{1}{c}{ Variable } & $\begin{array}{c}\text { Composite } \\
\text { Reliability }\end{array}$ \\
\hline Subjective Norms (NS) & 1.000 \\
\hline Image (CT) & 1.000 \\
\hline Self Confidence (KD) & 1.000 \\
\hline Anxiety (KC) & 0.732 \\
\hline Facilitating Conditions (KM) & 0.738 \\
\hline Perception of Enjoyment (KS) & 1.000 \\
\hline Perceived Ease of Use (KP) & 0.899 \\
\hline Perceived usefulness (KG) & 0.787 \\
\hline
\end{tabular}

Based on Table 6 , all variables in this study were declared reliable by having a composite reliability value $>0.7$. 


\subsection{R-square}

The R-Square value shows the explainability of the independent variable to the dependent variable. The greater the R-Square value, the more the independent variable can explain the dependent variable meaning the better the structural equation.

Table 7. R-square Results

\begin{tabular}{lc}
\hline \multicolumn{1}{c}{ Variable } & R-Square \\
\hline Image (CT) & 0.085 \\
\hline Perceived usefulness (KG) & 0.611 \\
\hline Perceived Ease of Use (KP) & 0.700
\end{tabular}

Based on table 7 , it can be seen that the Image Variable (CT) had an r-square value of 0.085 , meaning that the Subjective Norm Variable (NS) had an influence on the Image Variable (CT) by $8.5 \%$ and the remaining $91.5 \%$ was influenced by other variables.

Perceived usefulness $(\mathrm{KG})$ had an r-square value of
0.611, meaning that the Subjective Norm (NS), Image (CT) and Perceived Ease of Use (KP) variables had an influence on the Perceived usefulness (KG) by $61.1 \%$ and the remaining $38.9 \%$ was influenced by other.

Finally, the Perceived Ease of Use (KP) variable had a r-square value of 0.700 , meaning that the SelfConfidence (KD), Anxiety (KC), Facilitating Conditions (KM), and Perceptions of Enjoyment (KS) had an influence on the Perceived Ease of Use (KP) by $70.0 \%$ and the remaining $30 \%$ was influenced by other variables.

\subsection{Hypothesis Testing}

The hypothesis is an alleged statement about the relationship between two or more variables based on the researcher's reasoning or derived from an existing theory (Perdana et al., 2018). In the hypothesis test, the path coefficient is positive if $>0.1$ and negative if $<0.1$. The T-Statistics value can be declared significant if $>1.96$ and insignificant if $<1.96$.

Table 8. Hypothesis Testing Results

\begin{tabular}{lccl}
\hline \multicolumn{1}{c}{ Hypothesis } & Path Coefficient & T-Statistics & \multicolumn{1}{c}{ Description } \\
\hline H1: NS -> CT & $(+) 0.291$ & 2.793 & H1 had a positive and significant influence. \\
\hline H2: NS -> KG & $(-) 0.087$ & 0.925 & $\begin{array}{l}\text { H2 had a negative and insignificant } \\
\text { influence. }\end{array}$ \\
\hline H3: CT -> KG & $(+) 0.321$ & 2.612 & H3 Had a positive and significant influence. \\
\hline H4: KD -> KP & $(+) 0.213$ & 1.446 & $\begin{array}{l}\text { H4 Had a positive but insignificant } \\
\text { influence. }\end{array}$ \\
\hline H5: KC $>$ KP & $(-)-0.035$ & 0.364 & $\begin{array}{l}\text { H5 Had a negative and insignificant } \\
\text { influence. }\end{array}$ \\
\hline H6: KM -> KP & $(+) 0.164$ & 1.137 & $\begin{array}{l}\text { H6 Had a positive but insignificant } \\
\text { influence. }\end{array}$ \\
\hline H7: KS -> KP & $(+) 0.576$ & 4.492 & H7 Had a positive and significant influence. \\
\hline H8: KP $>$ KG & $(+) 0.588$ & 5.435 & H8 Had a positive and significant influence. \\
\hline
\end{tabular}

\section{Discussion}

The first hypothesis (H1) testing results showed that Subjective Norms (NS) had a positive influence on Image (CT). This can be seen from the T-Statistics value of 2.793 meaning significant influence because the value is $>1.96$ and has a path coefficient of 0.291 meaning positive influence because the value $>0.1$. Thus, it can be concluded that H1 (Subjective Norm (NS) has a significance and positive influence on Image (CT)) is accepted.

The second hypothesis (H2) testing results showed that Subjective Norms (NS) had a negative and insignificant influence on Perceived usefulness (KG). This can be seen from the T-Statistics value of 0.925 , meaning insignificant influence because the value $<1.96$ and has a path coefficient of -0.087 meaning negative influence because of the value $<0.1$. Thus, it can be concluded that $\mathrm{H} 2$ (Subjective Norms (NS) has a positive influence on Perceived usefulness (KG)) is rejected.

The third hypothesis (H3) testing results showed that image (CT) had a positive influence on perceived usefulness (KG). This can be seen from the T-Statistics value of 2.612 meaning significant influence because the value is $>1.96$ and has a path coefficient of 0.321 meaning positive influence because the value $>0.1$. Thus, it can be concluded that H3 (Image (CT) has a positive influence on Perceived usefulness (KG)) is accepted. 
The fourth hypothesis (H4) testing results showed that Self-Confidence (KD) had an insignificant but positive influence on Perceptions of Ease of Use (KP). This can be seen from the T-Statistics value of 1.446 , meaning significant influence because the value $>1.96$ and has a path coefficient of 0.213 meaning positive influence because the value $>0.1$. Thus, it can be concluded that $\mathrm{H} 4$ (Self-Confidence (KD) has a positive influence on Perceptions of Ease of Use (KP)) is rejected.

The fifth hypothesis (H5) testing results showed that anxiety (KC) had a negative influence on Perceptions of Ease of Use (KP). This can be seen from the T-Statistics value of 0.364 , meaning insignificant influence because the value $<1.96$ and has a path coefficient of -0.035 meaning negative influence because of the value $<0.1$. Thus, it can be concluded that H5 (Anxiety $(\mathrm{KC})$ has a negative influence on Perceptions of Ease of Use (KP)) is rejected.

The sixth hypothesis (H6) testing results showed that Facilitating Conditions (KM) had an insignificant but positive influence on Perceptions of Ease of Use (KP). This can be seen from the T-Statistics value of 1.137, meaning insignificant influence because the value $<1.96$ and has a path coefficient of 0.164 meaning positive influence because the value $>0.1$. Thus, it can be concluded that H6 (Facilitating Conditions (KM) has a positive influence on Perceptions of Ease of Use (KP)) is rejected.

The seventh hypothesis (H7) testing results showed that Perception of Enjoyment (KS) had a positive influence on Perceptions of Ease of Use (KP). This can be seen from the T-Statistics value of 4.492, meaning significant influence because the value is $>1.96$ and has a path coefficient of 0.576 meaning positive influence because the value $>0.1$. Thus, it can be concluded that H7 (Perception of Enjoyment (KS) has a positive influence on the Perception of Ease of Use (KP)) is accepted.

Based on the results, e-learning developers should improve the functionality of the existing system to have better features. An understanding of Google Drive also provides reasons for the management of educational institutions to take steps in terms of investment so that it can become the basis for the educational strategy planning process. Of course, this acceptance analysis does not only relate to the field of information system development, but other fields such as education management and the cloud computing industry. The results of this study can certainly provide the right information to stakeholders in education, the information systems industry, and cloud computing infrastructure in taking the right steps to develop their innovations.

\section{Conclusion}

This study aimed to determine the acceptance level of Google Drive in e-learning at STMIK Rosma by using the Technology Acceptance Model (TAM) 3 method. Based on the results, all students accepted Google Drive services for E-Learning at STMIK Rosma. This acceptance was based on four influential factors/relationships, namely the relationship between Subjective Norms (NS) on Image (CT), Relationship between Image (CT) and Perceived Usefulness (KG), Relationship between Perceived Enjoyment (KS) and Perceived Ease of Use (KP) and the relationship between perceived ease of use (KP) and perceived usefulness $(\mathrm{KG})$ by having a significant influence on Google Drive acceptance for e-learning at STMIK Rosma. In addition, there were four/ related variables with significant influence on Google Drive acceptance for E-Learning at STMIK Rosma, namely the relationship between Self-Confidence (KD) and Perceived Ease of Use (KP), the relationship between Anxiety (KC) and Perceived Ease of Use (KP) and the Relationship between Facilitating Conditions (KM) and Perceived Ease of Use (KP).

\section{References}

Adetimirin, A. (2015). An empirical study of online discussion forums by the library and information science postgraduate students using technology acceptance model 3. Journal of Information Technology Education: Research, 14(1), 257269. https://doi.org/10.28945/2269

Airifin, Z. (2009). Evaluasi Pembelajaran. PT. Remaja Rosdakarya.

Ari Saktiono, M. (2019). Penerapan Google Form Untuk Evaluasi Kehadiran Perkuliahan TarunaTaruni Teknika PDP UHT. Jurnal Aplikasi Pelayaran Dan Kepelabuhanan, 9(2), 113-119. https://doi.org/10.30649/jurapk.v9i2.70

Ariessanti, H. D., Warsito, A. B., \& Rumoma, N. (2012). Pemanfaatan Google Drive Sebagai Media Pembelajaran iLearning Pada Perguruan Tinggi Raharja. $x$, 11-22.

Ajzen, I., \& Fishbein, M. (1975). A Bayesian analysis of attribution processes. Psychological bulletin, 82(2), 261.

Balaji, D. R., Al-Mahri, F. A., \& Balaji, M. (2016). A Perspective Study on Content Management in ELearning and M-Learning. http://arxiv.org/abs/1605.02093

Chandra, F. S., \& Novita, D. (2020). Analisis Penerimaan Masyarakat Terhadap Layanan Transportasi Online Menggunakan UTAUT (Unified Theory of Acceptance and Use of Technology). Jurnal Teknologi Sistem Informasi, 1(1), 23-33. http://jurnal.mdp.ac.id/index.php/jtsi/article/vie w/319

Endang Fatmawati. (2015). Technology Acceptance Model (TAM) untuk Menganalisis Penerimaan 
Terasap Sistem Informasi Perpustakaan. Jurnal Iqra, 09(01), 1-13.

Fitriani, M. (2020). Analisis Teks Eksplanasi Berdasarkan Struktur dan Kaidah Kebahasaan pada Surat Kabar Galamedia. Repository.Unpas.Ac.Id

Karim, D., Sepang, J. L., Soepeno, D., \& Sepang, J. L. (2020). Pengaruh Relationship Marketing Dan Suasana Kafe Terhadap Loyalitas Pelanggan Di Rumah Kopi Billy Kawasan Megamas. Jurnal EMBA: Jurnal Riset Ekonomi, Manajemen, Bisnis Dan Akuntansi, 8(1). https://doi.org/10.35794/emba.v8i1.27361

Librado, D. (2017). Analisis Penerimaan Mahasiswa Terhadap Sistem Informasi Akademik (SIAKAD) dengan Metode Technology Acceptance Model (TAM). Jurnal SAINTEKOM, $7(2)$, 112-125. https://doi.org/10.33020/saintekom.v7i2.29

Nadiyah Hidayati, Y. R. (2020). Analisis Penerimaan dan Penggunaan Aplikasi Gojek menggunakan Model UTAUT (Studi Kasus: SMK MVP ARS Internasional). JAMI: Jurnal Ahli Muda Indonesia, 1(1). 85-95.

Nanda Ladepi. (2018). Penerimaan Sistem E-Filling (Studi Empiris pada Wajib Pajak Orang Pribadi).

Palapa, A., \& Saifudin, I. (2021). Analisa Pengaruh Technology Acceptance Model (TAM) Pada Aplikasi Pendaftaran Penilaian Training Record Book (Smile 05) Studi Pada PUKP 05 Semarang. Majalah Ilmiah Bahari Jogja, 19(1), 70-86. https://doi.org/10.33489/mibj.v19i1.259

Perdana, M. W., Herdiansyah, M. I., \& Mirza, A. H. (2018). Analisis Faktor-Faktor Keberhasilan Dan Implementasi Guru Pembelajar Online (Gpo) Pada Guru Smkn Di Kota Palembang Menggunakan Kerangka Kerja Hot-Fit Berbasis Smartpls. Jurnal Digital Teknologi Informasi, 1(1), 27-36. https://doi.org/10.32502/digital.v1i1.932

Prasetyo, B. (2016). Pengukuran Penerimaan Aplikasi Dreamspark Pada STIKOM Surabaya dengan Menggunakan Metode Technology Acceptance Model (TAM). 5-24.

Pudjastawa, A. W., \& Cantika, V. M. (2020). Penerapan Google Drive Bersama sebagai Perpustakaan Digital. Piwulang: Jurnal Pendidikan Bahasa Jawa, 8(2), 89-95. https://doi.org/10.15294/piwulang.v8i2.42114

Putra, Y. W. S., Kusrini, \& Wibowo, F. W. (2018). Analisis Penerimaan Sistem Informasi Rumah Sakit TAM. Citec Journal, 5(3), 161-173.

Putu Ayu Mira Witriyanti Wida, Ni Nyoman Kerti Yasa, \& Gede, I. P. (2016). Aplikasi Model TAM (Technology Acceptance Model) Pada Perilaku
Pengguna Instagram. JUIMA: Jurnal Ilmu Manajemen, 6(2).

Riski Nurida Rahmawati, \& I Made Narsa. (2019). Actual Usage Penggunaan E-Learning Dengan Technology Acceptance Model (TAM). 6(2), 127-136.

Roziqin, M. C., Rachmatta, D., Mudiono, P., \& Amalia, N. (2021). Analisis Penerimaan Simpus Ditinjau dari Persepsi Pengguna di Puskesmas Mojoagung dengan Metode TAM. Jurnal Teknologi Informasi Dan Ilmu Komputer (JTIIK), 8(1), $\quad 47-54$. https://doi.org/10.25126/jtiik.202182907

Rumini. (2019). Penerapan dan Pengelolaan Manajemen File dengan Google Drive untuk Guru TK ABA Perumnas Condong Catur Sleman. Seminar Hasil Pengabdian Masyarakat 2019, November.

Sakdiyah, L., Effendi, R., \& Kustono, A. S. (2019). Analisis Penerimaan Penggunaan E-Learning dengan Pendekatan Theory of Planned Behavior (TPB) pada Mahasiswa Akuntansi Universitas Jember. E-Journal Ekonomi Bisnis Dan Akuntansi, 6(2), 120-132. https://doi.org/10.19184/ejeba.v6i2.11151

Sefrika. (2018). Analisa Penerimaan Teknologi ELearning Pada AMIK BSI Jakarta. Journal of Informatic Pelita Nusantara, 3(1), 1-5. http://ejurnal.pelitanusantara.ac.id/index.php/JIPN/artic le/download/271/169

Setiawan, Adi, \& Sulistiowati, L. H. (2018). Penerapan Modifikasi Technology Acceptance Model (Tam) Dalam E-Business. Jurnal Manajemen Dan Pemasaran Jasa, 10(2), 171-186. https://doi.org/10.25105/jmpj.v10i2.2277

Setiawan, Ananto, Setyasih, R. D., \& Hosana, L. J. (2020). Analisis Faktor - Faktor Penggunaan Financial Technology pada Sistem Pembayaran Transportasi Online: Theory of Planned Behavior (TPB). Monex, 9, 30-37. http://ejournal.poltektegal.ac.id/index.php/mone $\mathrm{x} /$ article/view/1640

Setiawan, E. (2020). Analisis. Kamus Besar Bahasa Indonesia (KBBI). https://kbbi.web.id/analisis

Shandyastini, N. M., \& Novianti, K. D. P. (2016). Analisis E-Learning STMIK STIKOM Bali Menggunakan Techonology Acceptance ModeL. Jurnal TEKNOIF, 4(2), 1-6.

Sijabat, F., Sinuraya, E., Roos, C., \& Nainggolan, E. (2020). Pelatihan Nitro, Microsoft Picture Manage Dan Google Drive Di SMK Negeri 11 Medan. Jurnal Abdimas Mutiara, 1(September), 76-85.

Sirait, T. P. (2021). Faktor-Faktor Yang Mempengaruhi Turnover Intention Karyawan 
PT Pembangkitan Jawa Bali Services Amurang. Jurnal Administrasi Bisnis (JAB), 11(1), 29-36.

Surendran, P. (2012). Technology Acceptance Model: A Survey of Literature. International Journal of Business and Social Research (IJBSR), 2(4). 175-178

Trihandayani, A., \& Abdillah, L. A. (2019). Analisis Penerimaan Pengguna dalam Memanfaatkan Media Sosial Terhadap Usaha Kecil Menengah Menggunakan Metode Technology Acceptance Model (TAM). Bina Darma Conference Computer Science (BDCCS2019), september, 2214-2221.

Trilaksono, A. R. (2020). Efektivitas Penggunaan Google Drive Sebagai Media Penyimpanan Di Kalangan Mahasiswa. Jurnal Digital Teknologi Informasi, 1(2), 91-197. https://doi.org/10.32502/digital.v1i2.1651

Warsito, A. B., \& Yuliandini, E. (2017). Penerapan Google Drive Sebagai Media Penyimpanan Bahan Perkuliahan Dalam Mendukung Aplikasi Mobile App. Jurnal Ilmiah SISFOTENIKAJ, 7(2), 219-228.

Widyastuti, L., Suhaidar, S., \& Yunita, A. (2020). Analisis Penerimaan Teknologi Financial Anggregatir Cekaja.com terhadap Behavior Intention melalui Pendekatan Prilaku Rencanaan (Theory of Planned Behavior atau TPB) (Studi pada Masyarakat Kota Pangkalpinang). IJAB : Indonesian Journal of Accounting and Business, 1(2), $131-152$. https://doi.org/10.33019/accounting.v1i2.10 